\title{
A HAZARDOUS WASTE FROM SECONDARY ALUMINIUM METALLURGY AS A NEW RAW MATERIAL FOR CALCIUM ALUMINATE GLASSES
}

Aurora López-Delgado ${ }^{1}$, Hanan Tayibi, Carlos Pérez, Francisco José Alguacil and Félix Antonio López

National Centre for Metallurgical Research, CENIM, CSIC.

Avda, Gregorio del Amo, 8. 28040 Madrid. Spain. alopezdelgado@cenim.csic.es

\section{Abstract}

A solid waste coming from the secondary aluminium industry was successfully vitrified in the ternary $\mathrm{CaO}-\mathrm{Al}_{2} \mathrm{O}_{3}-\mathrm{SiO}_{2}$ system at $1500^{\circ} \mathrm{C}$. This waste is a complex material which is considered hazardous because of its behaviour in the presence of water or moisture. In these conditions, the dust can generate gases such as $\mathrm{H}_{2}, \mathrm{NH}_{3}$, $\mathrm{CH}_{4}, \mathrm{H}_{2} \mathrm{~S}$, along with heat and potential aluminothermy. Only silica sand and calcium carbonate were added as external raw materials to complete the glasses formula.

Different nominal compositions of glasses, with $\mathrm{Al}_{2} \mathrm{O}_{3}$ ranging between 20-54\%, were studied to determine the glass forming area. The glasses obtained allow the immobilisation of up to $75 \%$ of waste in a multicomponent oxide system in which all the components of the waste are incorporated. The microhardness $\mathrm{H}_{\mathrm{v}}$ values varied between 6.05-6.62 GPa and the linear thermal expansion coefficient, $\alpha$, varied between $(62-139) \times 10^{-7} \mathrm{~K}^{-1}$. Several glasses showed a high hydrolytic resistance in deionised water at $98^{\circ} \mathrm{C}$.

\footnotetext{
${ }^{1}$ Corresponding author
} 
Key words: hazardous waste, secondary aluminium industry, calcium aluminate glasses, vitrification 


\section{Introduction}

Secondary aluminium is obtained by a process involving the melting of aluminium scrap [1-8] and other materials or by-products containing this metal, and the technologies used vary from one plant to another depending on the scrap type, oxide content, presence of impurities, etc. These factors also influence the fluxes that are used to maximise the recovery of aluminium. The aluminium recycling industry is a beneficial activity for the environment since it recovers resources from primary industry, manufacturing and post-consumer waste. The industry is sensitive to social pressures for it to reduce its environmental impact, and proposes to achieve an appropriate technology with zero discharges. Some of the technical actions taken to improve recycling activities include: i) maximum metal recovery, taking into account the materials available on the aluminium waste and scrap market. The aim is to recover the materials with the lowest metal content, which are the cheapest; and ii) waste minimisation. This is focused in two directions: minimising the generation of waste and ensuring that it can subsequently be recycled $[9,10]$.

The obtaining of secondary aluminium by the melting of scrap and other byproducts generates several types of slag which are classified according to their aluminium and salt contents [1]. In general terms the treatment of these slags consists of milling, shredding and subsequent granulometric classification. The coarsest fractions have a higher metallic content and are commercialised for various uses within the aluminium industry or in other metallurgical industries (synthetic slag, deoxidiser in ladle metallurgy, etc.). Besides these commercialisable fractions, milling also generates powdery solids of a very fine grain size which are collected by suction systems and 
trapped in sleeve filters. These fines, of a granulometry of less than $50 \mu \mathrm{m}$, constitute what is known as aluminium dust (Ald). The amount of dust generated, and its chemical, mineralogical and granulometric composition depends not only on the type and quality of the processed scrap but also on the classification and trapping methods that are used. Ald consists principally of Al metal, Si metal, spinel $\left(\mathrm{MgAl}_{2} \mathrm{O}_{4}\right)$, corundum $\left(\mathrm{Al}_{2} \mathrm{O}_{3}\right)$, aluminium nitride, aluminium carbide, aluminium sulfide, quartz $\left(\mathrm{SiO}_{2}\right)$ and minor phases such as sodium and potassium chlorides and fluorides, iron oxides and silicates. In general terms the average chemical composition of Ald ranges $25-40 \% \mathrm{Al}_{\text {total }}, 15-25 \% \mathrm{Al}_{\text {metal }}, 1-3 \% \mathrm{C}, 0.2-1 \% \mathrm{~S}, 1-6 \% \mathrm{~N}, 6-11 \% \mathrm{SiO}_{2}$, $1-3 \% \mathrm{Ca}, 2-5 \% \mathrm{Mg}, 1-3 \% \mathrm{Na}, 0.2-1 \% \mathrm{~K}, 0.5-2 \% \mathrm{Fe}$ and $1-5 \% \mathrm{~F}$, among others [1]. In Spain, the Ald production is estimated at $\sim 13 \mathrm{~kg} / \mathrm{t}$ of treated aluminium scrap, which means the generation of an important volume of this waste [1].

From an environmental viewpoint, Ald is classified as a toxic and hazardous waste. Its toxicity is basically due to its high reactivity in the presence of water or environmental humidity and is related with the generation of gases $\left(\mathrm{H}_{2}, \mathrm{CH}_{4}, \mathrm{NH}_{3}\right.$ and $\mathrm{H}_{2} \mathrm{~S}$ ), heat and potential aluminothermy [11]. The treatment of this waste has traditionally consisted of storage in secure sites. However, this type of management is now being questioned and several new approaches to its treatment have focused on the development of inertisation procedures to allow its storage in landfills [12-15].

The vitrification of waste materials is a well established technology [16-19]. Nevertheless, strictly from the point of view of inertisation, this option only seems to be economically viable when applied to radioactive waste. For other wastes, further applications of the vitrified waste could justify the economics of this technology. 
Bearing in mind the latter, $\mathrm{CaO}-\mathrm{Al}_{2} \mathrm{O}_{3}-\mathrm{SiO}_{2}$ system was selected as a variant of the binary calcium aluminate glass system to be used in the vitrification of Ald. Glasses and melts in the binary $\mathrm{CaO}-\mathrm{Al}_{2} \mathrm{O}_{3}$ system have been moderately studied in last years in comparison with common sodium-calcium glasses [20-41]. Theses glasses are highly considered for their optical properties [23], but they exhibit a tendency towards devitrification [35]. The addition of small amount of a network former as $\mathrm{SiO}_{2}$ improves the glass stability [21, 35-37]. In addition, a glass system such as $\mathrm{CaO}-\mathrm{Al}_{2} \mathrm{O}_{3}-\mathrm{SiO}_{2}$ could yield devitrified materials or glass ceramic materials with interesting properties: low expansion coefficient, good dielectric properties, high hardness and abrasion resistance, thermal stability, etc. [37].

The selection of the $\mathrm{CaO}-\mathrm{Al}_{2} \mathrm{O}_{3}-\mathrm{SiO}_{2}$ system was also based on two practical considerations: the use of the least possible additional reagents as raw materials for the obtainment of the glasses and the low cost of these raw materials. Thus, the preparation of calcium silicoaluminate glasses will only need silica sand and calcium carbonate as raw materials, in addition to the aluminium-rich waste as a source of $\mathrm{Al}_{2} \mathrm{O}_{3}$.

The purpose of the present work was to formulate glasses in the $\mathrm{CaO}-\mathrm{Al}_{2} \mathrm{O}_{3}-\mathrm{SiO}_{2}$ system. This objective was approached bearing in mind the above considerations and focusing on both the immobilisation of an aluminium-rich waste and valorisation of this waste through the use of the glass products obtained.

\section{Experimental}

Aluminium dust (Ald) was provided by a secondary aluminium melter. The asreceived waste $(400 \mathrm{~kg}$ ) was homogenized in a mixer and then successively quartered to 
get a representative sample of $20 \mathrm{~kg}$. Then this sample was quartered again to get samples of $1 \mathrm{~kg}$ which were used in this work. The granulometric analysis (Coulter LS Particle Size Analyzer) yielded values of 3 and $11 \mu \mathrm{m}$ for the singular parameters d50 and $\mathrm{d} 90$ respectively. The aluminum content was quantitatively determined by atomic absorption spectrometry (AAS, Varian Mod Spectra AA-220 FS). The values obtained were $35.1 \%$ for total aluminiun $\left(66.2 \%\right.$ expressed as $\left.\mathrm{Al}_{2} \mathrm{O}_{3}\right)$ and $16.5 \%$ for metal aluminium. A value of $5.9 \%$ of $\mathrm{SiO}_{2}$ was obtained by gravimetry determination by applying the Standard ASTM E34-88. The content of nitrure and sulfure of aluminium was calculated by the determination of $\mathrm{NH}_{3}$ and $\mathrm{SH}_{2}$ according to the standard EPA 9030 and 9010 respectively; values of 12.2 and $2.2 \%$ were obtained for $\mathrm{AlN}$ and $\mathrm{Al}_{2} \mathrm{~S}_{3}$ respectively. Others components were determined by X-ray fluorescence (XRF) (Philips PW 1404 sequential wavelength dispersion unit) yielding, wt. \%: $8.7 \mathrm{MgO}, 3.9 \mathrm{CaO}$, $2.5 \mathrm{Na}_{2} \mathrm{O}, 1.36 \mathrm{~K}_{2} \mathrm{O}, 1.40 \mathrm{Fe}_{2} \mathrm{O}_{3}, 1.45 \mathrm{ZnO}, 4.2 \mathrm{~F}, 0.9 \mathrm{Cl}, 0.38 \mathrm{CuO}, 1.46 \mathrm{TiO}_{2}, 0.36$ $\mathrm{PbO}$ and $0.22 \mathrm{NiO}$. From the chemical analysis results, the potentially high reactivity of the waste can be pointed out, because of the generation of toxic gases such as $\mathrm{H}_{2}, \mathrm{NH}_{3}$ and $\mathrm{H}_{2} \mathrm{~S}$, in the presence of humidity (Eq. 1-3) [1].

$$
\begin{array}{lll}
2 \mathrm{Al}+3 \mathrm{H}_{2} \mathrm{O} & \longrightarrow 3 \mathrm{H}_{2}(\mathrm{~g})+\mathrm{Al}_{2} \mathrm{O}_{3} \\
2 \mathrm{AlN}+3 \mathrm{H}_{2} \mathrm{O} & \longrightarrow & 2 \mathrm{NH}_{3}(\mathrm{~g})+\mathrm{Al}_{2} \mathrm{O}_{3} \\
\mathrm{Al}_{2} \mathrm{~S}_{3}+3 \mathrm{H}_{2} \mathrm{O} & \longrightarrow 3 \mathrm{H}_{2} \mathrm{~S}(\mathrm{~g})+\mathrm{Al}_{2} \mathrm{O}_{3}
\end{array}
$$

The mineralogical composition was determined by X-ray diffraction (XRD) (SIEMENS model D 5000 diffractometer) with CuK $\alpha$ radiation (scanning rate: $0.03^{\circ}$ 20/s). The principal crystalline phases detected (Figure 1) were Al metal, spinel 
$\left(\mathrm{MgAl}_{2} \mathrm{O}_{4}\right)$, aluminum nitride $(\mathrm{AlN})$, corundum $\left(\mathrm{Al}_{2} \mathrm{O}_{3}\right)$, Si metal, quartz $\left(\mathrm{SiO}_{2}\right)$ and iron oxide $\left(\mathrm{Fe}_{3} \mathrm{O}_{4}\right)$.

To prepare glasses, different compositions were formulated to be melted from Ald and other chemical reagents: washed quartz sand as $\mathrm{SiO}_{2}$ precursor and $\mathrm{CaCO}_{3}$ as $\mathrm{CaO}$ precursor. No other reagents were added. The glass-forming area was investigated. Batch melting $(100 \mathrm{~g})$ were carried out in a high alumina refractory crucible using an electrical muffle furnace (Thermoconcept HT0417). The heating rate schedule included several heating stages: a fast first step up to $550^{\circ} \mathrm{C}$ (heating rate, $11^{\circ} \mathrm{C} \cdot \mathrm{min}^{-1}$ ) and the maintaining of this temperature for $30 \mathrm{~min}$ to calcine the reagents; a slower heating step (heating rate, $7^{\circ} \mathrm{C} \cdot \mathrm{min}^{-1}$ ) up to $900^{\circ} \mathrm{C}$ to permit the foaming of sample; and a third step (heating rate, $20^{\circ} \mathrm{C} \cdot \mathrm{min}^{-1}$ ) up to $1500{ }^{\circ} \mathrm{C}$ for melting. Finally a slight temperature increase up to $1525^{\circ} \mathrm{C}$ was maintained for $15 \mathrm{~min}$ in order to favour the glass refining and the better pouring of sample. The melts were cast onto a hot steel mould in air and the glasses were then immediately annealed at temperatures from 600 to $700^{\circ} \mathrm{C}$ for $1 \mathrm{~h}$ and slowly cooled $\left(3^{\circ} \mathrm{C} \cdot \mathrm{min}^{-1}\right)$ to room temperature.

The glassy or crystalline character of the materials obtained was confirmed by XRD

Several mechanical and physical properties were assessed by different techniques. The real density of glasses was determined by a Helium picnometer (Micromeritcs mod. Accupy 1330). The working conditions were: pressure of $1.5 \mathrm{Bar}$ and a cell of $10 \mathrm{~cm}^{3}$. Bulks samples were used for the measurements. Five determinations were carried out for each sample.

The determination of mechanical properties, microharness and fracture toughness, was carried out on the polished surface of the specimens. Vickers 
microhardness $\left(\mathrm{H}_{v}\right)$ was obtained from microindentation method in a Wilson Wolpert model 401 MVA apparatus. A variable load (1.8 and 9.8 N), depending on glasses, was applied for $15 \mathrm{~s}$ to the polished surface of the samples. Numerous indentations were performed for each sample and at least seven well-defined examples were selected for measurements. Vickers microhardness was calculated by means of the equation (4) [42]:

$$
H_{v}=\frac{P}{\text { contactarea }}=\frac{0.322 P}{a^{2} \operatorname{sen} 136^{\circ}}=\frac{0.464 P}{a^{2}}
$$

$\mathrm{P}$ being the indentation pressure and $2 \mathrm{a}$ the average value of the crak diagonal

The fracture toughness $\left(\mathrm{K}_{I C}\right)$, was estimated from the length of the cracks which are formed at the corners of the Vickers prism using the equation 5 [43],

$$
K_{I C}=0.048\left(\frac{c}{a}\right)^{-1.32}\left(\frac{E}{H_{v}}\right)^{0.4} H_{v} \sqrt{a}
$$

E being the Young' modulus, and $2 \mathrm{c}$ the crack size. According to the literature $[25,44$, 45] and the chemical composition of glasses, an estimated Young's modulus value of 90 GPa was used.

The thermal expansion coefficient of glasses was recorded in annealed and planoparallel samples with a Netzsch model 402 EP differential dilatometer. The measurement error was $<1 \%$. Transition temperatures $\left(\mathrm{T}_{\mathrm{g}}\right)$ and linear expansion coefficient $(\alpha)$ data were determined from dilatometric curves.

Differential Thermal Analysis (DTA) was carried out in SETSYS Evolution 1750 equipment. Samples of glasses $(30 \mathrm{mg})$ were milled to a grain size $<50 \mu \mathrm{m}$. Tests 
were performed in $100 \mu \mathrm{l}$ alumina crucibles up to $1200{ }^{\circ} \mathrm{C}$, in a dynamic helium atmosphere $(20 \mathrm{ml} / \mathrm{min})$ at the heating rate of $20^{\circ} \mathrm{C} / \mathrm{min}$.

The hydrolytic resistance of the glasses was studied in deionised water $(\mathrm{pH} 4.80$ \pm 0.02 , conductivity $7.9 \mathrm{M} \Omega . \mathrm{cm}$ ) at $98^{\circ} \mathrm{C}$ for $1 \mathrm{~h}$, according to the standard UNE $43-708$ 75. The glasses were milled to a grain size of between 0.32 and $0.50 \mathrm{~mm}$. The crystalline or glassy character of samples after the hydrolytic test was determined by XRD.

\section{Results and discussion}

\subsection{Composition and forming area.}

Samples were prepared in the $\mathrm{CaO}-\mathrm{Al}_{2} \mathrm{O}_{3}-\mathrm{SiO}_{2}$ system according to the nominal composition summarised in Table 1. The macroscopic appearance is also included. All the glasses obtained were dark-green coloured, the higher the Ald content the darker the glass colouring. Ingots of $60 \times 15 \times 10 \mathrm{~mm}$ in size were obtained for all the samples except for samples 1 and 15 , which it was not possible to pour. The few surface crystals and the partially devitrified surface observed in some samples may be attributed to the cooling process during casting, whose rate was not as fast as is necessary to obtain glasses without surface crystallisation. In addition to the macroscopic appearance, the structure of the samples was also examined by XRD. Figure 2 shows the XRD patterns of the samples (samples 1, 2, 4 and 15 were not analyzed because of their partially crystalline aspect). Samples 3, 5-14, exhibited an amorphous-like XRD pattern. Only very few 
surface crystals of spinel, $\mathrm{MgAl}_{2} \mathrm{O}_{4}$, were detected in samples 3 and 7 and the diffraction line of quartz, $\mathrm{SiO}_{2}$, was observed in sample 8 .

The ternary diagram for the $\mathrm{CaO}-\mathrm{Al}_{2} \mathrm{O}_{3}-\mathrm{SiO}_{2}$ system and the compositions prepared (glasses and melts) are shown in Figure 3. The glass-forming area is delimited by dots. Opal glasses were excluded of the forming area. Sample 15 was also excluded because of the partial devitrification of the surface, although glasses could actually be obtained with this composition, probably by improving the cooling process and sample 14 was considered to be on the border of the glass-forming area. It can be observed that glasses with a variable content of $\mathrm{Al}_{2} \mathrm{O}_{3}$, ranging between 20 and $50 \%$ may be obtained. Taking into account the content of $\mathrm{Al}_{2} \mathrm{O}_{3}$ in the waste, this figure indicates the possibility of immobilising between 30 and $75 \%$ of waste, depending on the glass composition. From the point of view of incorporating the highest amount of waste, glasses 3, 5, 6, 7 and 8 allowed the adding of more than $60 \% \mathrm{w} / \mathrm{w}$ of waste.

\subsection{Mechanical properties}

Several micrographs of the cracks produced by the Vicker microindenter in several glasses are shown in Figure 4. In general, the crack morphology is characteristic of isotropic materials. Crack propagation is irregular and, in some cases, the maximum stress does not correspond with the vertex of the Vickers prism. Lateral and ramified cracks were also observed. For microhardness calculation, only indentation marks with perfect crack formation and propagation were considered.

Table 2 shows the Vickers microhardness and toughness values of all the glasses. Density values are also included. The $\mathrm{H}_{\mathrm{v}}$ values range between 6.1 and 6.6 GPa. 
Sampaio et al. [25] reported values of 7.9 and 5.6 GPa for calcium aluminosilicate glasses and silicate glasses respectively; Scarinci et al. [19] reported values ranging between 5.8 and $6.2 \mathrm{GPa}$ for glasses obtained by vitrification of municipal incinerator waste . It can be seen that Vickers microhardness value increases with $\mathrm{Al}_{2} \mathrm{O}_{3}$ content, as is to be expected in a mixed network progressively reinforced with $\mathrm{Al}_{2} \mathrm{O}_{3}$. This can be much better observed in Figure 5, which shows the variation of microhardness with $\mathrm{SiO}_{2} / \mathrm{Al}_{2} \mathrm{O}_{3}$ ratio.

The $\mathrm{K}_{\mathrm{IC}}$ values obtained (0.8-1.3) are within the range to those reported in the literature for different types of glasses. Thus Romero et al. [45] reported a $\mathrm{K}_{I C}$ value of 1.1 $\mathrm{MPa} . \mathrm{m}^{1 / 2}$ for $\mathrm{SiO}_{2}-\mathrm{MgO}-\mathrm{CaO}$ glass from municipal solid waste incinerator fly ash; McColm [47] reported $\mathrm{K}_{I C}$ values of $0.8 \mathrm{MPa} \cdot \mathrm{m}^{1 / 2}$ for $\mathrm{SiO}_{2}-\mathrm{Al}_{2} \mathrm{O}_{3}$ glasses; Sampaio et al. [25] reported values of 1.4 and 1.2 $\mathrm{MPa} \cdot \mathrm{m}^{1 / 2}$ calcium aluminosilicate glasses and silicate glasses respectively. Only sample 6 exhibits a anomalous high value (1.5 MPa.m ${ }^{1 / 2}$ ), which might be attributable to an inaccurate estimation of $\mathrm{E} . \mathrm{K}_{I C}$ values also increases with $\mathrm{Al}_{2} \mathrm{O}_{3}$ content. No clear tendency of both parameters, $\mathrm{H}_{V}$ and $\mathrm{K}_{I C}$ can be concluded in relation with the $\mathrm{CaO}$ percentage.

Density values vary between 2.71 and $2.89 \mathrm{~g} . \mathrm{cm}^{-3}$. For samples with less than $48 \%$ of $\mathrm{Al}_{2} \mathrm{O}_{3}$, the higher $\mathrm{Al}_{2} \mathrm{O}_{3}$ content the higher density.

\subsection{Thermal properties.}

Table 3 lists the thermal expansion coefficients $(\alpha)$ of the glasses calculated from their expansion curves in the $20-300^{\circ} \mathrm{C}$ range along with the transition temperatures $\left(\mathrm{T}_{\mathrm{g}}\right)$. $\alpha$ varies from $63 \times 10^{-7} \mathrm{~K}^{-1}$ to $139 \times 10^{-7} \mathrm{~K}^{-1}$. Sample 8 exhibits a very 
high $\alpha$ value compared to the other samples. Glasses composed principally by aluminium oxide and calcium oxide are highly refractory and they have a high thermal expansion coefficient [46]. No clear tendency was found in relation with the oxide percentages of each glass. The transition temperatures of the glasses ranged between 505 and $761^{\circ} \mathrm{C}$. A general $\mathrm{T}_{\mathrm{g}}$ increase with the $\mathrm{CaO}$ (a glass modifier) percentage of the glasses was observed.

Figure 6 shows the DTA curves of glasses 3, 5, 6, 7 and 8 (the curves corresponding to the other glasses were not included for the purposes of clarity, but the results of differential thermal analysis of all the glasses are shown in Table 4.). In these curves, several endothermic and exothermic effects can be observed. First of all a small endothermic effect is observed between 640 and $826^{\circ} \mathrm{C}$, which corresponds to the glass transition $\left(T_{t}\right)$. These values are higher than those obtained by dilatometric measurements. The second effect appears as a high exothermic peak at temperature between 860 and $990{ }^{\circ} \mathrm{C}$, which may be attributed to the crystalline phases formation $\left(\mathrm{T}_{\mathrm{c}}\right)$. In glasses 7 and 12 a second exothermic peak is observed at temperature of 1072 and $983{ }^{\circ} \mathrm{C}$, close to the former. The crystalline phase formation temperature is one of the most important parameter for studying the devitrification of glasses to order to obtain glass-ceramic materials [50]. In several glasses, small residual endothermic peaks can be observed around $1200^{\circ} \mathrm{C}$ which corresponds to liquid phases formation $\left(\mathrm{T}_{1}\right)$. This is the case of samples 7 .

As shown in Figure 7 the value of $\mathrm{T}_{\mathrm{g}}$ in general increases as the ratio $\mathrm{Al}_{2} \mathrm{O}_{3} / \mathrm{CaO}$ increases, this means that $T_{g}$ increases with increasing waste content. In the case of glasses with similar $\mathrm{Al}_{2} \mathrm{O}_{3} / \mathrm{CaO}$, a higher $\mathrm{T}_{\mathrm{g}}$ is obtained when the $\mathrm{SiO}_{2}$ content is higher; thus, the higher content of a network former, as $\mathrm{SiO}_{2}$, the higher $\mathrm{T}_{\mathrm{g}}$ value. Higby et al. 
[36] reported the same tendency of $\mathrm{T}_{\mathrm{g}}$ with $\mathrm{Al}_{2} \mathrm{O}_{3} / \mathrm{CaO}$ ratio for low-silica calcium aluminosilicate glasses.

\subsection{Hydrolytic resistance}

Hydrolytic tests performed on glasses are useful study their chemical resistance in order to be used in different applications. After the treatment with deionised boiling water all the specimens maintained the macroscopic glassy appearance except for samples 11 and 14, which showed a matt and powdery aspect, thus indicating loss of the glassy character of these specimens. These two glasses were prepared with the highest $\mathrm{CaO} / \mathrm{Al}_{2} \mathrm{O}_{3}$ ratio and with a low $\mathrm{SiO}_{2}$ content. Figure 8 shows the XRD patterns of the glasses after hydrolytic experiments. As can be seen, samples 3, 6-10, 12 and 13 exhibited similar XRD profiles to those corresponding to the samples prior to the hydrolytic test. In the case of sample 11 , diffraction lines of katoite $\left(\mathrm{Ca}_{3} \mathrm{Al}_{2}(\mathrm{OH})_{12}\right)$ and cowlesite $\left(\mathrm{CaAl}_{2} \mathrm{Si}_{3} \mathrm{O}_{10} \cdot 6 \mathrm{H}_{2} \mathrm{O}\right)$ were identified and for sample 14, katoite $\left(\mathrm{Ca}_{3} \mathrm{Al}_{2}(\mathrm{OH})_{12}\right)$ and clinoenstatite $\left(\mathrm{MgSiO}_{3}\right)$ were identified. Sample 5, despite maintaining the macroscopic glassy appearance, showed a crystalline structure corresponding to spinel and quartz phases. It can be due to the chemical attack promoted to the surface of some glasses by the boiling water. This is addressed to the initial adsorption of water

molecules to the glass surface and then the exchange between the $\mathrm{H}^{+}$-ions of water by the monovalent ions (in general, alkaline ions) of the glass surface. As a consequence, dealkalinisation of the glass surface occurs, yielding the formation of crystalline deposits, as well as local differences in the glass composition. Moreover, the glass 
surface can be relatively enriched in the less leachable oxides, i.e. silica and/or alumina, which could become some of their corresponding crystalline phases; however an interpretation of the behaviour of those samples in boiling water is not easy due to the complexity of the glasses composition.

\section{Conclusions}

Vitrification has been demonstrated to be a suitable immobilisation procedure for an aluminium-rich waste. Glasses were formulated and prepared in the ternary $\mathrm{CaO}-$ $\mathrm{Al}_{2} \mathrm{O}_{3}-\mathrm{SiO}_{2}$ system. Glasses formulated and prepared in this system allow the successful immobilisation of high proportions of the aforementioned waste (up to $75 \%$ of waste). The values of Vickers microhardness and toughness obtained are comparable to those reported for calcium aluminosilicate glasses. The wide glass-forming area also allows the preparation of various types of glasses; this might confer an advantage for possible applications as $\mathrm{Al}_{2} \mathrm{O}_{3}$ raw materials for glass industry. Only glasses with high $\mathrm{CaO} / \mathrm{Al}_{2} \mathrm{O}_{3}$ ratio and low $\mathrm{SiO}_{2}$ content were susceptible to chemical attack with boiling water. Crystallization temperature was determined for a further obtaining of glassceramic materials.

\section{Acknowledgments}

The authors thank the MEC for financing project CTM2005-01964 and the company Recuperaciones y Reciclajes Roman S.L. (Fuenlabrada, Madrid, Spain) for supplying 
Ald. We would also like to thank Dr.M. A. Villegas and M. García-Heras for you helpful insight and Mr. A. Delgado for his technical assistance. H. Tayibi is grateful to the CSIC (Spanish National Research Council) for an I3P contract (I3PDR-6-01).

\section{References}

[1] A. López-Delgado, H. Tayibi, F.A. López, Treatments of aluminium dust-a hazardous residue from secondary aluminium industry, in: G. Mason Leonora (Ed.), Focus on hazardous materials research, Nova Publishers, 2007, pp. 1-52.

[2] J.P. Edward, T.T. William, S.K. George, Precoated Baghouse Control for Secondary Aluminum Smelting, For Presentation at the $71^{\text {st }}$ Annual Meeting of the Air Pollution Control Association, Houston, Texas, 25-30 June, 1978.

[3] B. Zhou, Y. Yang, M.A. Reuter, U.M.J. Boin, Modelling of aluminium scrap melting in a rotary furnace, Min. Eng. 19 (2006) 299-308.

[4] K. Venkat, G.R. Rmana, Recycling of Aluminum Based Materials in Ionic Liquids, Recycling and Waste treatment in Mineral and Metal Processing: Technical and Economic Aspects, Lulea, Sweden, 16-20 June, 2002.

[5] B. Zhou, Y. Yang, M.A. Reuter, Study of Melting Behaviour of Aluminium Scraps in Molten Melts. Recycling and Waste treatment in Mineral and Metal Processing: Technical and Economic Aspects, Lulea, Sweden, 16-20 June, 2002.

[6] Y. Xiao, M.A. Reuter, Recycling of distributed aluminium turning scrap, Min. Eng. 15 (2002) 963-970.

[7] R.P. Pawluk, Report in brief: Secondary aluminum and remelting, ALUM. 78 (2002) 38-39. 
[8] H. Gripenberg, J. Lodin, O. Falk, F. Niedermair, New tools for melting of secondary aluminium in rotary furnaces, ALUM. 78 (2002) 642-646.

[9] M. Díaz, A.D. Parralejo, A.G. Macías, J.M.P. Sánchez-Marín, Reciclado de materials, Puertas a la lectura, 6 and 7, 41-48.

[10] M.P. Tomas, A.H. Wortz, The ecological demands and practice for Recycling of Aluminum, Resour. Conserv. Recycl. 10 (1994) 193-204.

[11] US EPA, Toxicity Test Procedure, Federal Register, 40 CFR, Part 261.23, 1980.

[12] F.A. López, A. López-Delgado, Procedimiento de estabilización/compactación de polvos de aluminio, P200200313 (ES2197797), 2002.

[13] A. López-Delgado, J. Medina, P. Alonso, H. Tayibi, C. Pérez, F.A. López, Estudio del comportamiento térmico del polvo de aluminio estabilizado con el yeso, Rev. Metal. Madrid. Extr. (2005) 330-334.

[14] H. Tayibi, C. Pérez, F.A. López, A. López-Delgado, Evolución de las propiedades mecánicas de un residuo de la metalurgia secundaria del aluminio estabilizado con el yeso, Rev. Metal. Madrid. 41 (2005) 280- 285.

[15] F.A. López, M.C. Peña, A. López-Delgado, Hydrolysis and heat treatment of aluminum dust, J. Air Waste Manage. 51 (2001) 903-912.

[16] E. Bernardo, M. Varrasso, F. Cadamuro, S. Hreglich, Vitrification of wastes and preparation of chemically stable sintered glass-ceramic products, J. Non-Cryst. Solids. 352 (2006) 4017-4023.

[17] F.A. López, E. Sáinz, A. López-Delgado, L. Pascual, J.M. Fernández-Navarro, The use of blast furnace slag and derived materials in the vitrification of electric arc furnace dust, Metal. Mat. Trans. B. 27B (1996) 379-384. 
[18] C.T. Li, W.J. Lee, K.L. Huang, S.F. Fu, Y.C. Lai, Vitrification of chromium electroplating sludge, Environ. Sci. Technol. 41 (2007) 2959-2956.

[19] G. Scarinci, G. Brusantin, L. Barvieri, A. Corradi, I. Lancellotti, P. Colombo, S. Hreglich, R. Dall'Igma, Vitrification of industrial and natural wastes with production

[20] W.Y. Li, B.S. Mitchell, Nucleation and crystallization in calcium aluminate glasses, J. Non-Cryst. Solids 255 (1999) 199-207.

[21] J.K.R. Weber, J.A. Tangeman, T.S. Key, K.J. Hiera, P.F. Paradis, T. Ishikawa, J.D. Yu, S. Yoda, Novel synthesis of calcium oxide-aluminium oxide glasses, Japanese J. Appl. Phys. Part 1. 41 (2002) 3029-3030.

[22] C.J. Benmore, J.K.R. Weber, S. Sampath, J. Siewenie, J. Urquidi, J.A. Tangeman, A neutron and X-ray diffraction study of calcium aluminate glasses, J. Phys. Cond. Matter. 15 (2003) 2413-2423.

[23] E.T. Kang, S.J. Lee, A.C. Hannon, Molecular dynamics simulations of calcium aluminate glasses, J. Non-Cryst. Solids 352 (2006) 725-736.

[24] Q. Mei, C.J. Benmore, S. Sampath, J.K.R. Weber, K. Leinenweber, P. Johnston, J.L. Yarger, The structure of permanently densified CaAl2O4 glass, J. Phys. Chem. Solids. 67 (2006) 2106-2110.

[25] J.A. Sampaio, M.L. Baesso, S. Gama, A.A. Coelho, J.A. Eiras, I.A. Santos, Rare earth doping effect on the elastic moduli of low silica calcium aluminosilicate glasses, J of Non-Cryst. Solids.304 (2002) 293-298.

[26] S.J. Saggese, J.A. Harrington, Calcium-aluminate glass for use as $\mathrm{n}<1$ hollow waveguides in the delivery of $\mathrm{CO}_{2}$ laser energy, Optical Mat. 2 (1993) 119-123. 
[27] M.E. Lines, J.B. MacChesney, K.B. Lyons, A.J. Bruce, A.E. Miller, K. Nassau, Calcium aluminate glasses as pontential ultralow-loss optical materials at 1.5-1.9 $\mu \mathrm{m}$, J.of Non-Cryst. Solids 107 (1989) 251-260.

[28] H. Hosono, Y. Abe, Photochromism of reduced calcium aluminate glasses, Mat. Research Bulletin, 23 (1988) 171-176.

[29] H. Hosono, Y. Abe, Photosensitivity and structural defects in dopant-free ultraviolet-sensitive calcium aluminate glasses, J. of Non-Cryst. Solids 95-96, Part $2(1987) 717-724$.

[30] J.A. Sampaio, T. Catunda, F.C.G. Gandra, S. Gama, A.C. Bento, L.C.M. Miranda, M.L. Baesso, Structure and properties of water free $\mathrm{Nd}_{2} \mathrm{O}_{3}$ doped low silica calcium aluminate glasses, J. of Non-Cryst. Solids 247 (1999) 196-202.

[31] M.L. Baesso, A.C. Bento, A.A. Andrade, T. Catunda, J.A. Sampaio, S. Gama, Neodymium concentration dependence of thermo- optical properties in low silica calcium aluminate glasses, J. of Non-Cryst. Solids 219 (1997) 165-169.

[32] E.V. Uhlmann, M.C. Weinberg, N.J. Kreidl, L.L. Burgner, R. Zanoni ,K.H. Church, Spectroscopic properties of rare-earth-doped calcium-aluminate-based glasses, J. of Non-Cryst. Solids 178 (1994) 15-22.

[33] A.M. Malyarevich, Yu.V. Volk, K.V. Yumashev, V.K. Pavlovskii, S.S. Zapalova, O.S. Dymshits, A.A. Zhilin, Absorption, emission and absorption saturation of $\mathrm{Cr}^{4+}$ ions in calcium aluminate glass, J. of Non-Cryst. Solids 351 (2005) 3551-3555.

[34] J.A. Sampaio, S. Gama, M.L. Baesso, T. Catunda, Fluorescence quantum efficiency of $\mathrm{Er}^{3+}$ in low silica calcium aluminate glasses determined by modemismatched thermal lens spectrometry, J. of Non-Cryst. Solids, 351 (2005) 15941602. 
[35] F.T. Wallenberger, N.E. Weston, S.D. Brown, Calcium aluminate glass fibers: drawing from supercooled melts versus inviscid melt spinning, Mat. Letters, 11 (1991) 229-235.

[36] P.L. Higby, R.J. Ginther, I.D. Aggarwal, E.J. Friebele, Glass formation and thermal properties of low-silica calcium aluminosilicate glasses. J. of Non-Cryst. Solids 126 (1990) 209-215.

[37] L. Cormier, D.R. Neuville, G. Calas, Structure and properties of low-silica calcium aluminosilicate glasses. J. of Non-Cryst. Solids 274 (2000) 110-114.

[38] F. Fondeur, B.S. Mitchell, Infrared studies of preparation effects in calcium aluminate glasses, J. of Non-Cryst. Solids 224 (1998) 184-190.

[39] J.E. Shelby, Formation and Properties of Calcium Aluminosilicate Glasses, J. Amer. Ceram. Soc 68 (1985) 155-158.

[40] R.G. Kuryaeva, Degree of polymerization of aluminosilicate glasses and melts, Glass Phys. Chem. 30 (2004) 157-166.

[41] A.L. Berezhnoi, Glass-ceramics and photo-sitalls, Ed. Plenum Press, New York, 1970.

[42] I.J. McColm, Ceramic Hardness. Plenum Press, New York, 1990.

[483 A.G. Evans, T.R. Wilshaw, Quasi-static solid particle damage in brittle solids. 1. Observations, analysis and implications, Acta Metall. 24 (1976) 939-956.

[44] B.R. Lawn, A.G. Evans, D.B. Marshall, Elastic/plastic indentation damage in ceramics: The median/radial crack system, J. Am.Ceram.Soc. 63 (1980) 574-581.

[45] M. Romero, R.D. Rawlings, J.M. Rincón, Development of a new glass-ceramic by means of controlled vitrification and crystallisation on inorganic wastes from urban incineration, J Eur. Ceram Soc. 19 (1999) 2049-2058. 
[46] J. M. Fernández Navarro, El vidrio, CSIC Soc. Española de Cerámica y Vidrio. Madrid, 2003. 


\section{Figure legends}

Fig.1. XRD pattern of Ald (1- $\mathrm{Al}, 2-\mathrm{Al}_{2} \mathrm{O}_{3}, 3-\mathrm{AlN}$, 4- $\mathrm{SiO}_{2}, 5-\mathrm{Si}, 6-\mathrm{MgAl}_{2} \mathrm{O}_{4}, 7-$ $\mathrm{Fe}_{3} \mathrm{O}_{4}$ ). Intensities in arbitrary units (a.u).

Fig. 2. XRD pattern of glasses (1- $\mathrm{MgAl}_{2} \mathrm{O}_{4}$, spinel, 2- $\mathrm{SiO}$, quartz). Intensities in arbitrary units (a.u).

Fig. 3. Ternary diagram for the $\mathrm{CaO}-\mathrm{Al}_{2} \mathrm{O}_{3}-\mathrm{SiO}_{2}$ system showing the compositions prepared and the glass-forming area.

Fig. 4. Micrographs of the cracks produced by Vickers microindenter in glasses: a) 6, b) 5 , c) 8 , d) 7 and e) 10 .

Fig. 5. Variation of Vickers microhardness with the $\mathrm{SiO}_{2} / \mathrm{Al}_{2} \mathrm{O}_{3}$ ratio.

Fig. 6. DTA curves for several selected glasses. ( $\mathrm{T}_{\mathrm{g}}$ Glass transition, $\mathrm{T}_{\mathrm{c}}$ Cristallization, $\mathrm{T}_{1}$ Formation of liquid phase)

Fig. 7. Variation of $\mathrm{T}_{\mathrm{t}}$ obtained from DTA with the $\mathrm{Al}_{2} \mathrm{O}_{3} / \mathrm{CaO}$ content.

Fig. 8. XRD pattern of glasses after hydrolytic resistance experiments (1- SiO2, quartz;

2- $\mathrm{MgAl}_{2} \mathrm{O}_{4}$, spinel; 3- $\mathrm{Ca}_{3} \mathrm{Al}_{2}(\mathrm{OH})_{12}$, katoite; 4- $\mathrm{MgSiO}_{3}$ clinoenstatite; 5$\mathrm{CaAl}_{2} \mathrm{Si}_{3} \mathrm{O}_{10} \cdot 6 \mathrm{H}_{2} \mathrm{O}$, cowlesite). Intensities in arbitrary units (a.u). 
Table 1.

Nominal composition of the glasses prepared and macroscopic appearance.

\begin{tabular}{|c|c|c|c|c|}
\hline \multirow[t]{2}{*}{ Sample } & \multicolumn{3}{|c|}{$\begin{array}{l}\text { Nominal Composition } \\
\text { (wt. \%) }\end{array}$} & \multirow[t]{2}{*}{$\begin{array}{l}\text { Macroscopic } \\
\text { appearance }\end{array}$} \\
\hline & $\mathrm{CaO}$ & $\mathrm{Al}_{2} \mathrm{O}_{3}$ & $\mathrm{SiO}_{2}$ & \\
\hline 1 & 40 & 54 & 6 & partially melt \\
\hline 2 & 40 & 50 & 10 & opal glass \\
\hline 3 & 45 & 49 & 6 & $\begin{array}{l}\text { glass with few } \\
\text { surface crystals }\end{array}$ \\
\hline 4 & 40 & 45 & 15 & opal glass \\
\hline 5 & 45 & 45 & 10 & glass \\
\hline 6 & 50 & 44 & 6 & $\begin{array}{l}\text { glass with few } \\
\text { surface crystals }\end{array}$ \\
\hline 7 & 45 & 40 & 15 & $\begin{array}{l}\text { glass with few } \\
\text { surface crystals }\end{array}$ \\
\hline 8 & 50 & 40 & 10 & $\begin{array}{l}\text { glass with few } \\
\text { surface crystals }\end{array}$ \\
\hline 9 & 40 & 35 & 25 & glass \\
\hline 10 & 50 & 35 & 15 & glass \\
\hline 11 & 65 & 35 & 0 & $\begin{array}{l}\text { glass with few } \\
\text { surface crystals }\end{array}$ \\
\hline 12 & 60 & 30 & 10 & glass \\
\hline 13 & 50 & 25 & 25 & glass \\
\hline 14 & 70 & 20 & 10 & $\begin{array}{l}\text { glass with } \\
\text { devitrified surface }\end{array}$ \\
\hline 15 & 80 & 20 & 0 & $\begin{array}{l}\text { glass with } \\
\text { devitrified bulk }\end{array}$ \\
\hline
\end{tabular}


Table 2.

Density, Vickers microhardness $\left(\mathrm{H}_{V}\right)$ and toughness $\left(\mathrm{K}_{I C}\right)$ of glasses

\begin{tabular}{|c|c|c|c|c|c|}
\hline Sample & $\begin{array}{l}\mathrm{d} \\
\left(\mathrm{mg} \cdot \mathrm{m}^{-3}\right) \\
\mathrm{X} 10^{-3}\end{array}$ & $\begin{array}{l}\mathrm{H}_{V} \\
(\mathrm{GPa})\end{array}$ & $\operatorname{Std}_{\mathrm{H} V}^{1}$ & $\begin{array}{l}\mathrm{K}_{I C} \\
\left(\mathrm{MPa} \cdot \mathrm{m}^{1 / 2}\right)\end{array}$ & $\operatorname{Std}_{\mathrm{KIC}}{ }^{2}$ \\
\hline 3 & 2.77 & 6.37 & 0.17 & 0.8 & 0.07 \\
\hline 5 & 2.83 & 6.59 & 0.14 & 1.1 & 0.10 \\
\hline 6 & 2.75 & 6.62 & 0.15 & 1.5 & 0.08 \\
\hline 7 & 2.87 & 6.51 & 0.06 & 0.9 & 0.14 \\
\hline 8 & 2.75 & 6.59 & 0.10 & 1.1 & 0.08 \\
\hline 9 & 2.74 & 6.40 & 0.13 & $*$ & $*$ \\
\hline 10 & 2.85 & 6.38 & 0.10 & 0.9 & 0.19 \\
\hline 11 & 2.84 & 6.59 & 0.08 & 0.8 & 0.07 \\
\hline 12 & 2.85 & 6.60 & 0.25 & 1.0 & 0.20 \\
\hline 13 & 2.71 & 6.05 & 0.10 & 1.3 & 0.13 \\
\hline 14 & 2.89 & 6.39 & 0.15 & 1.0 & 0.12 \\
\hline
\end{tabular}


Table 3.

Thermal properties (linear expansion coefficient, $\alpha$; and glass transition temperature, $\mathrm{T}_{\mathrm{g}}$ )

\begin{tabular}{|l|l|l|}
\hline Sample & $\alpha_{20-300 \text { degrees }}\left(\mathrm{K}^{-1}\right)$ & $\mathrm{T}_{\mathrm{g}}\left({ }^{0} \mathrm{C}\right)$ \\
\hline 3 & $62.7 \times 10^{-7}$ & 563.5 \\
\hline 5 & $80.2 \times 10^{-7}$ & 504.7 \\
\hline 6 & $75.9 \times 10^{-7}$ & 665.9 \\
\hline 7 & $75.3 \times 10^{-7}$ & 760.2 \\
\hline 8 & $139.4 \times 10^{-7}$ & 570.2 \\
\hline 9 & $98.6 \times 10^{-7}$ & 774.0 \\
\hline 10 & $75.6 \times 10^{-7}$ & 756.3 \\
\hline 11 & $97.2 \times 10^{-7}$ & 767.6 \\
\hline 12 & $76.2 \times 10^{-7}$ & 759.2 \\
\hline
\end{tabular}


Table 4.

Glass transition temperature $\left(T_{g}\right)$, crystallization temperature $\left(T_{c}\right)$ and liquid phase formation temperature $\left(\mathrm{T}_{1}\right)$, obtained by DTA.

\begin{tabular}{|l|l|l|l|}
\hline Sample & $\mathrm{T}_{\mathrm{g}}\left({ }^{\circ} \mathrm{C}\right)$ & $\mathrm{T}_{\mathrm{c}}\left({ }^{\circ} \mathrm{C}\right)$ & $\mathrm{T}_{1}\left({ }^{\circ} \mathrm{C}\right)$ \\
\hline 3 & 798 & 905 & 1337 \\
5 & 787 & 910 & n.o \\
7 & 707 & 864 & 1255 \\
8 & 823 & 941 & 1189 \\
9 & 788 & 887 & n.o. \\
10 & 827 & 971 & n.o. \\
11 & 826 & 979 & n.o. \\
12 & - & 943 & n.o. \\
14 & 643 & 956 & n.o. \\
\hline
\end{tabular}

n.o.: not observed 


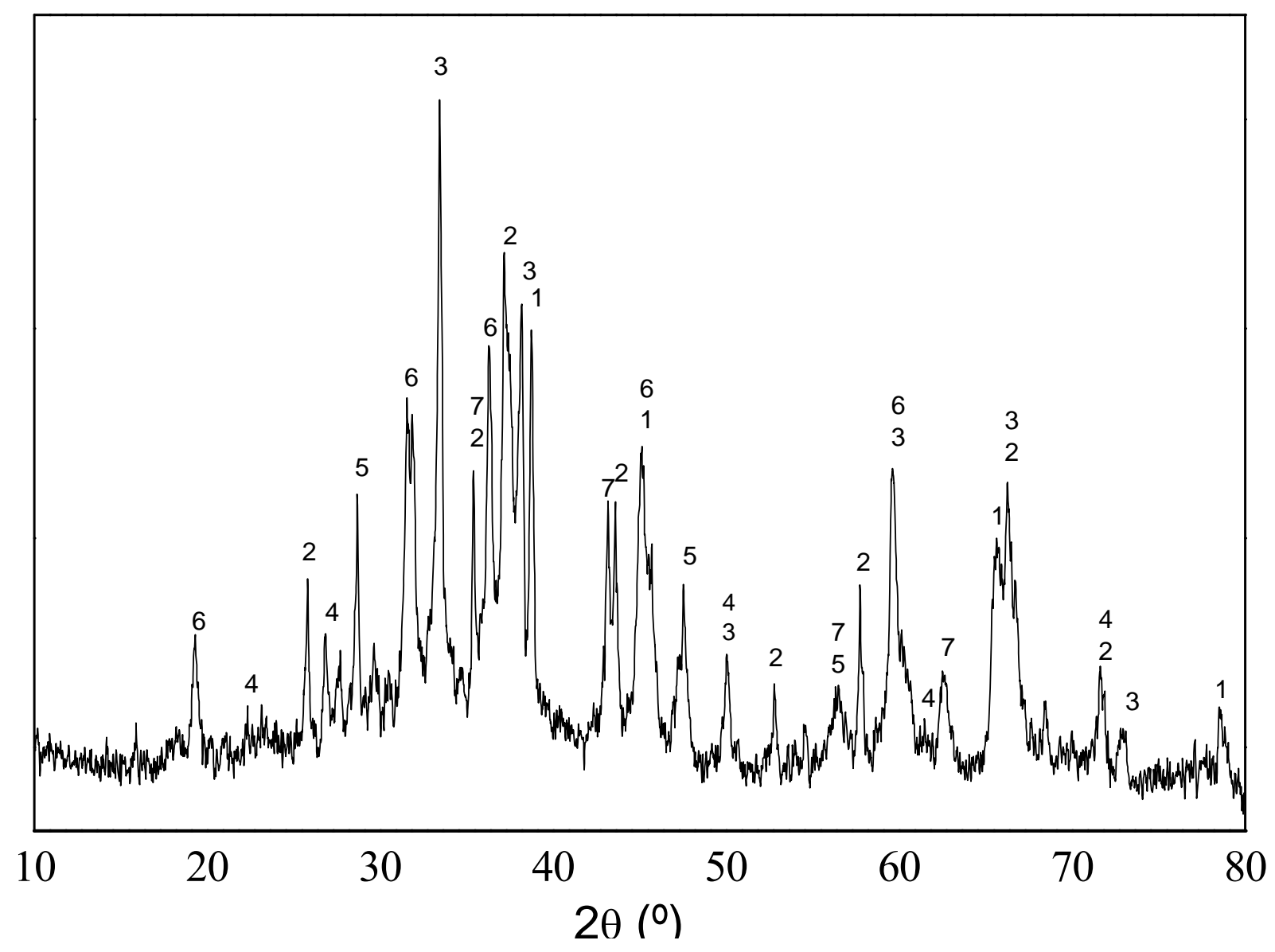

Figure 1 


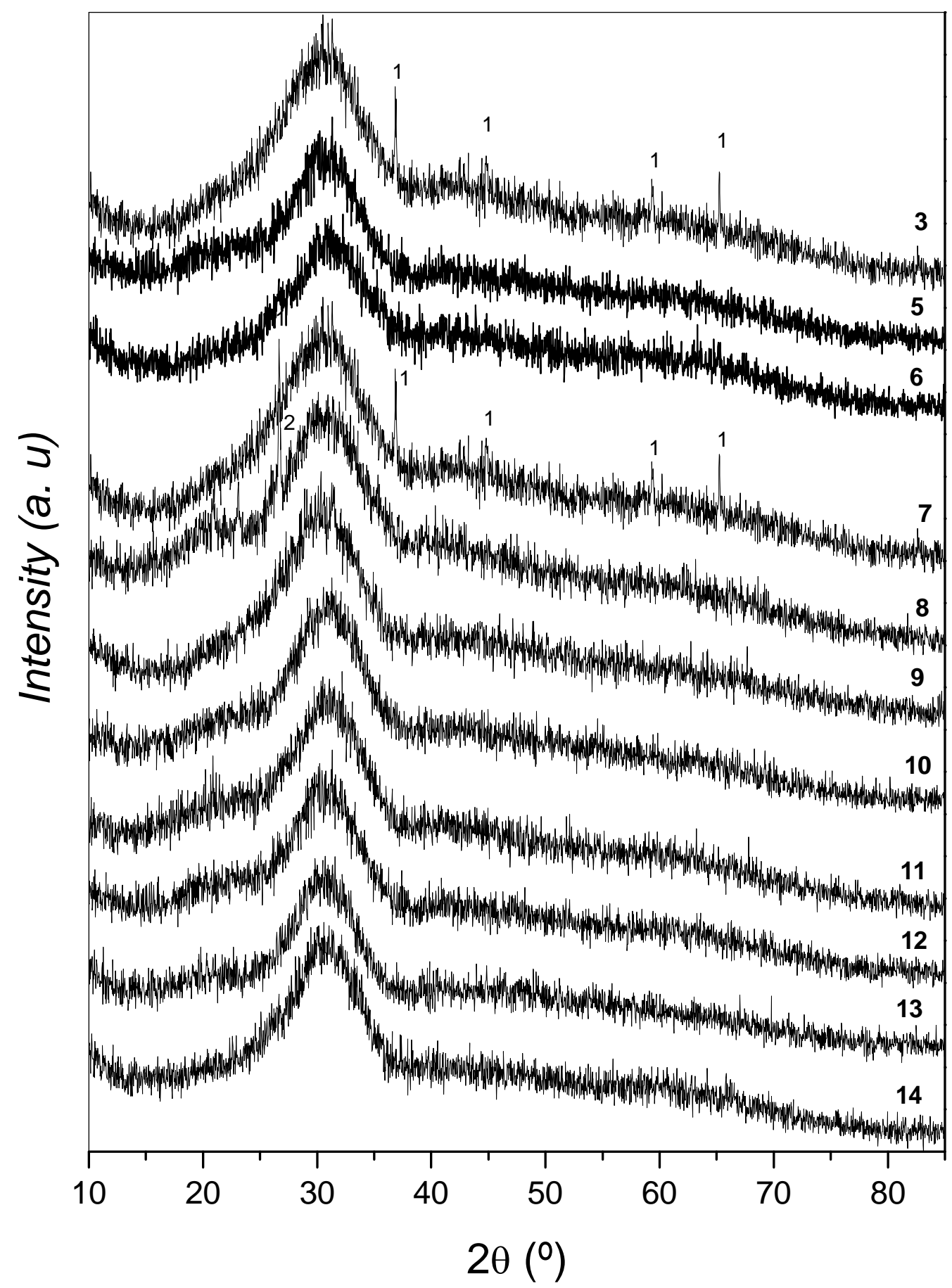

Figure 2 


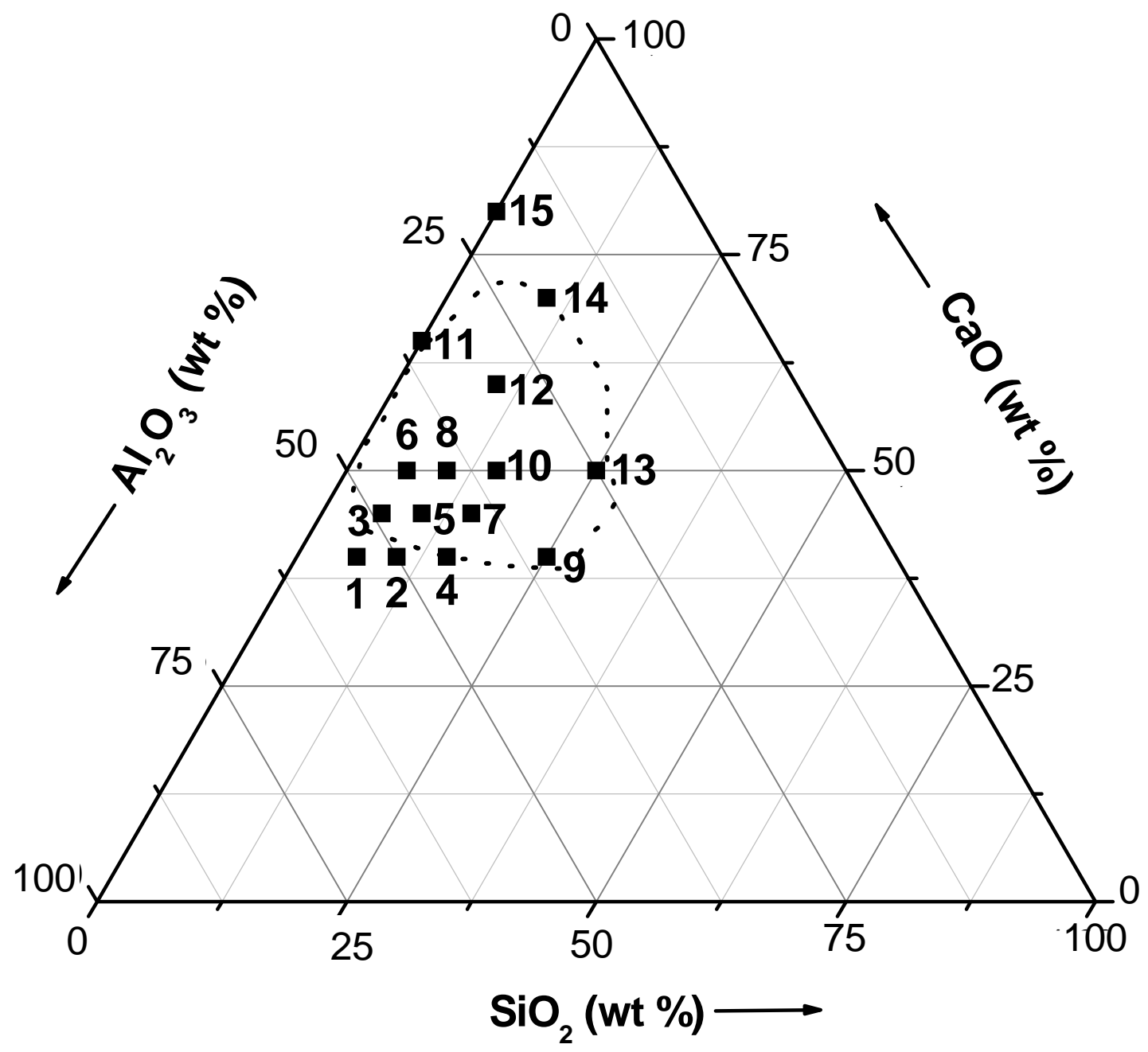

Figure 3 


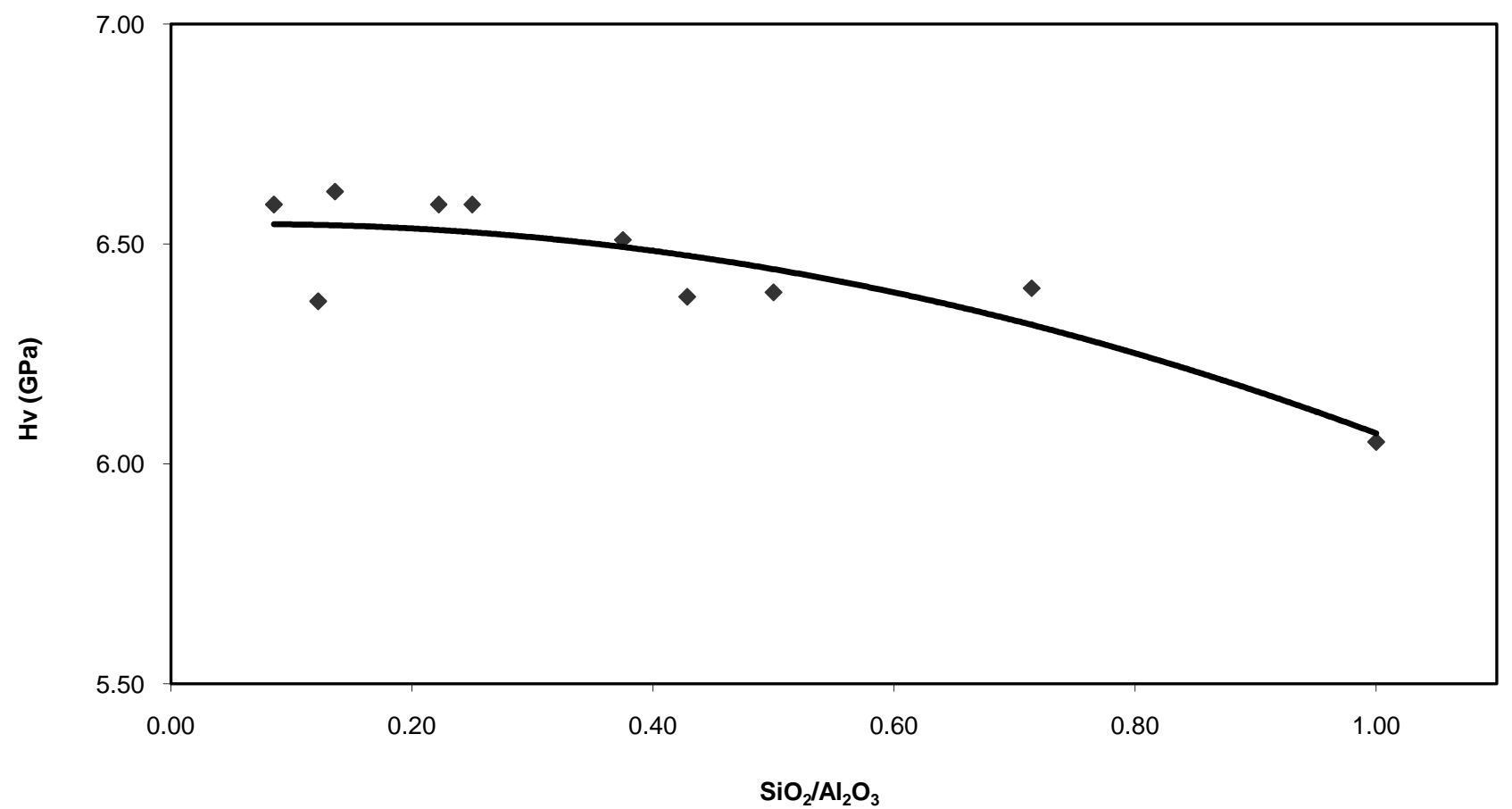

Figure 5 


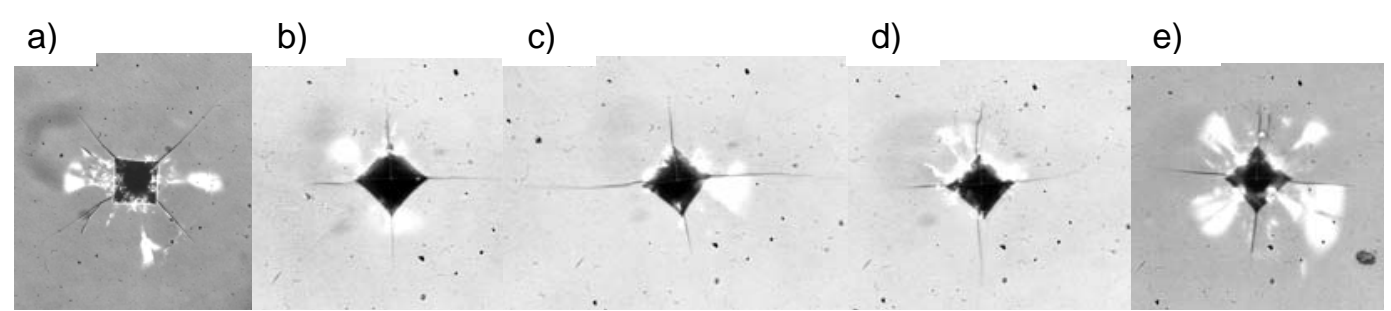

Figure 4 


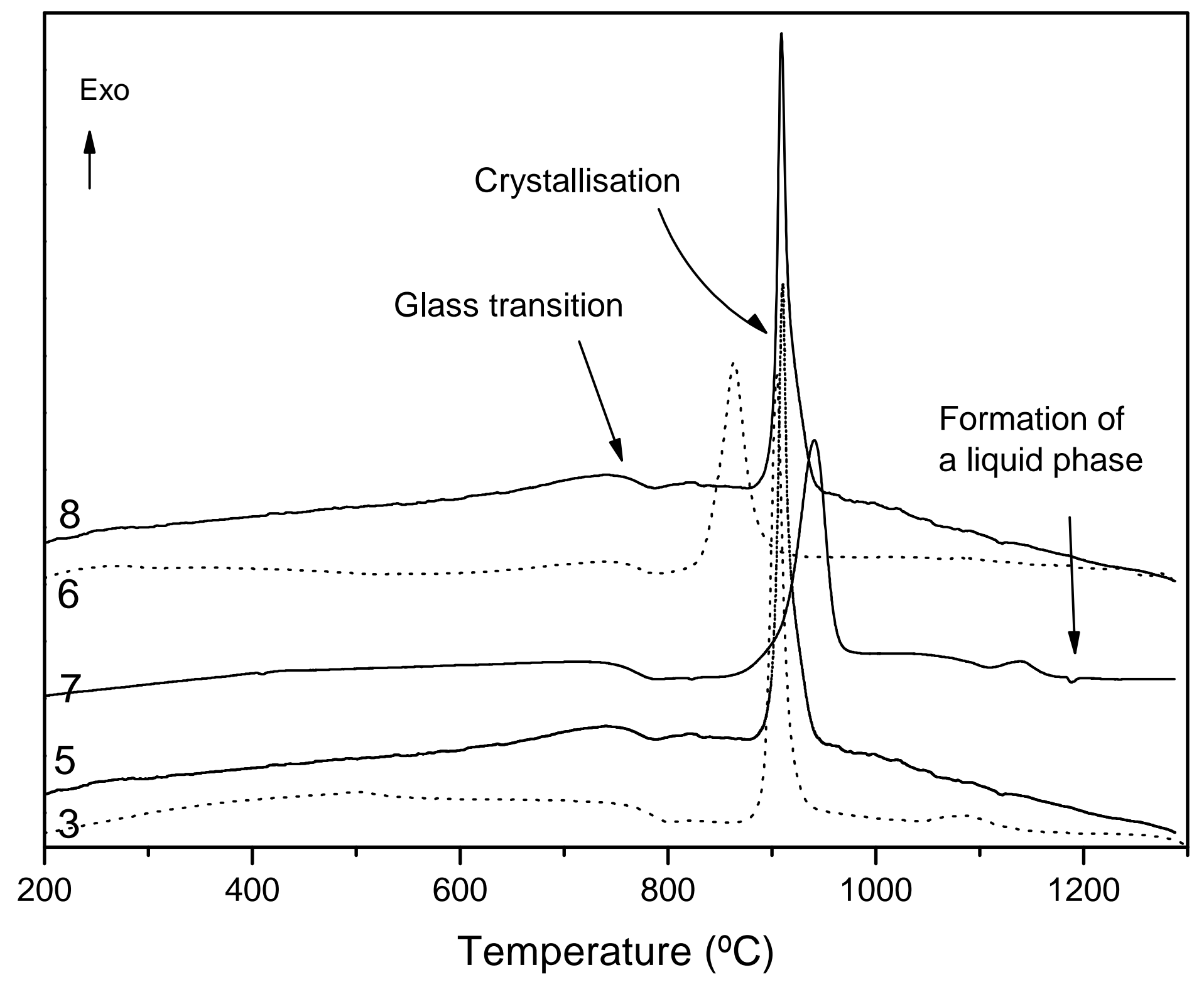




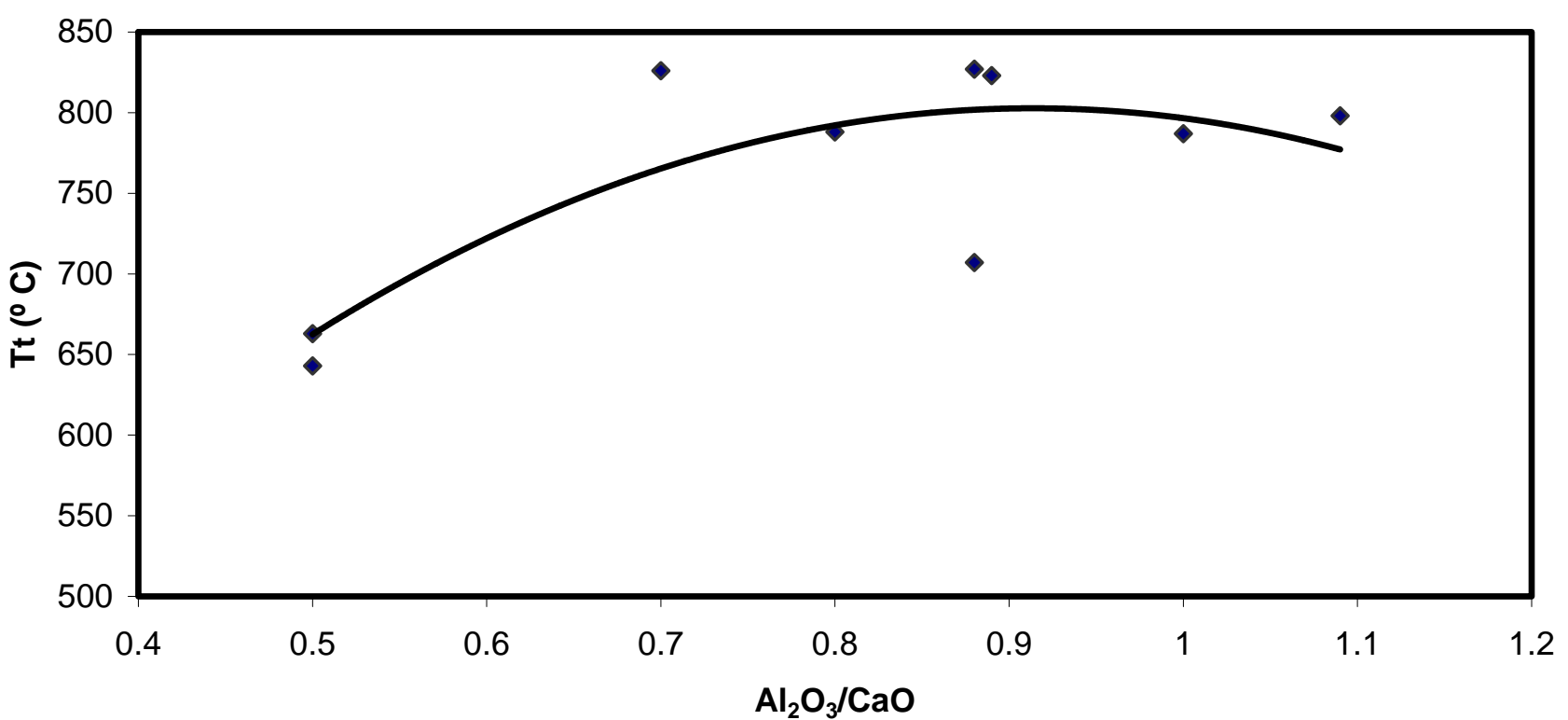

Figure7 


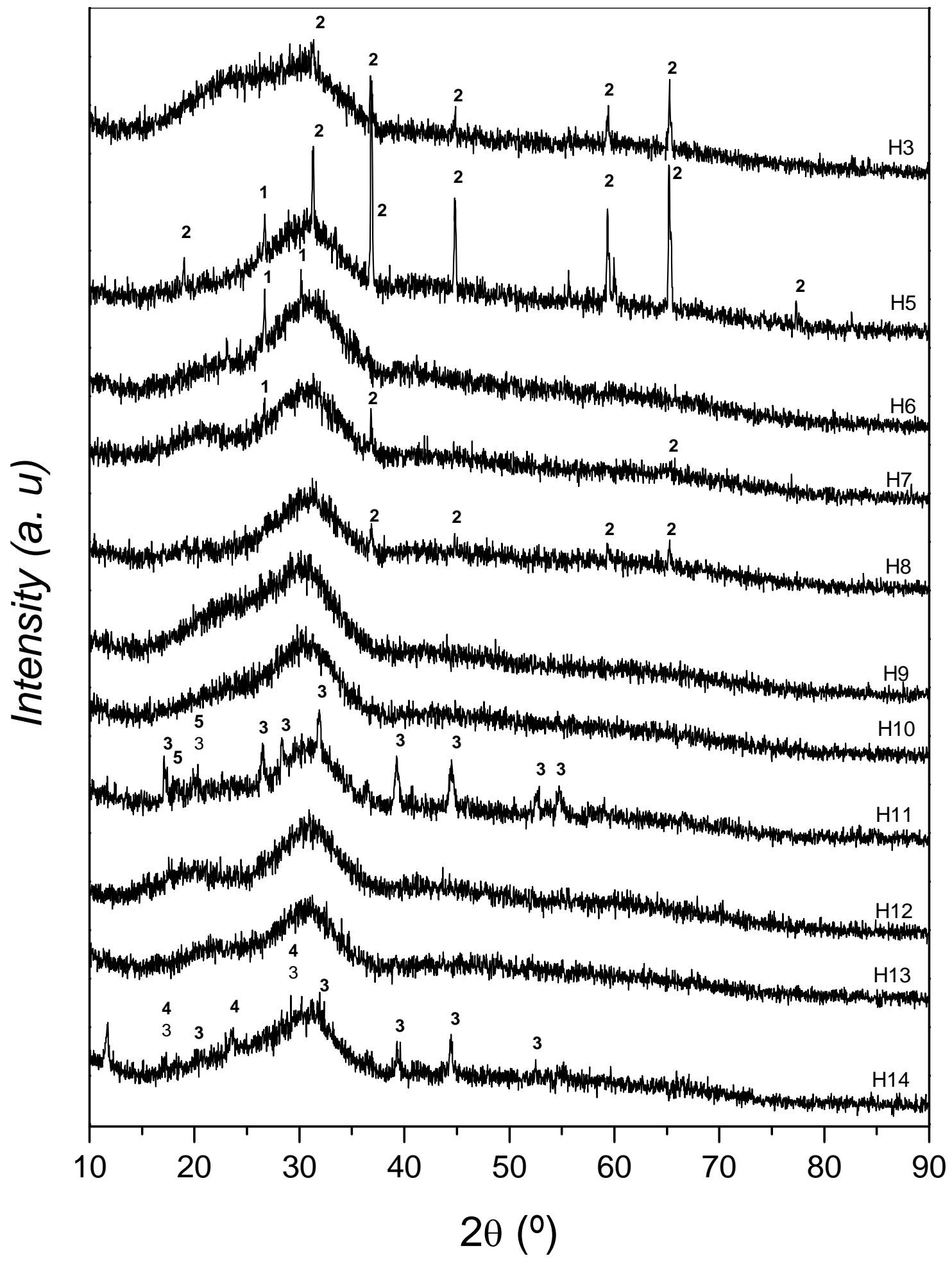

Figure 8 